\title{
The Effect Of Easy Perception And Security Perception On The Intention Of Using Shopeepay Through Attitude As Intervening Variables In Madiun
}

\author{
Heny Sidanti ${ }^{1}$, Dian Citaningtyas Ari Kadi ${ }^{2}$, Hari Purwanto ${ }^{3}$, Wahyu Sri Lestari ${ }^{4}$ \\ 1,2,3,4 PGRI Madiun University \\ *Corresponding Author : \\ Email : henysidanti75@gmail.com
}

\begin{abstract}
.
The purpose of this research was to determine the effect of perceived ease of use and perceived safety on Intention to Use through Attitude as an Intervening Variable for ShopeePay Users in Madiun. This research is a quantitative study using sampling techniques using nonprobability sampling with purposive sampling technique. Respondents of this study were 150 people. Data analysis used classical assumption test, hypothesis test, path analysis, and Sobel test mediation. Based on the results of the test ( $t)$, obtained the results of the perception of ease of perception and perceptions of security affect attitudes, perceptions of perceived ease of security affect intention to use with a significant value less than the alpha value of 0.05 . The path analysis test obtained the results of the indirect sub-structural effect 1 Ease of perception on the intention to use through attitude as an intervening variable obtained the result that the direct effect was greater than the indirect effect. Results The indirect effect of perceptions of security on the intention to use through attitude as an intervening variable shows that the direct effect is smaller than the indirect effect. The results of the Sobel test mediation test show that the results of the perception of Security on Intention to Use through Attitude as an Intervening Variable can mediate attitudes.
\end{abstract}

Keywords: Perception of Ease, Perception of Security, Attitudes, Intention to Use

\section{INTRODUCTION}

With the shift in the change in payment transaction methods starting with the bartering payment method for goods, paper money is now experiencing changes and developments that can be enjoyed by the people in Indonesia, namely changes in cash payments can be made with non-cash payments via ATMs and credit cards and electronic wallets (e-wallets). According to Bank Indonesia data, there are 2 types of noncash payments in Indonesia, namely Chip Based and Server Based. The difference between the two is that the Chip Based payment method uses cards provided by banks such as debit. Meanwhile, server-based payment methods use server-based support that can be accessed through websites or applications (e-wallets) such as Dompetku, Shoopepay, DANA. Changes in this method are not only experienced by consumers, but business actors are also developing new strategies for payment methods to be in line with changes in payment methods. (https://www.paper.id) Changes in payments in the digital era are supported by the increasing use of the internet in Indonesia. According to survey data by APPJII (Internet Service Providers Association, it shows that the number of internet users in Indonesia for the 2019-second quarter / 2020 period reached 198.7 million people and experienced an increase of 23.5 million or $8.9 \%$ compared to 2018 . This will be an opportunity for business people to take advantage of the increase in internet use to increase their business with internet-based electronic media. Consumers will be presented with the convenience provided by business people to make buying and selling transactions. (https://databoks.katadata.co.id) The increase in internet usage is equivalent to the use of changing transaction methods to meet consumer needs, such as the use of digital wallets related to the internet to access the applications provided to use non-cash payment methods.

Consumers will dominate in a situation that makes them feel that they are getting the desired result in making transactions and enjoying the facilities that are offered so as not to be left behind by current trends.Data can be informed that there has been an increase in the volume and value of electronic money transactions. Volume is the amount of electronic money circulating in society at a certain period, while the value of electronic money is the value of money stored electronically in an application or media that can be transferred for payment transactions or fund transfers. So, data on the volume of electronic money transactions at the end of 2018 jumped by 943.3 million transactions and in July 2019 the value of electronic 
money transactions in 2018 was Rp. 69 trillion (https://databoks.katadata.co.id). The presence of applicationbased e-wallets in Indonesia is a special attraction for Indonesians who previously used cash payments. Ewallets are server-based electronic devices whose use is to make online payment transactions with other users to make buying and selling transactions of goods and services. The use of e-wallets must be accompanied by internet access that can access the e-wallet application. Examples of e-wallets in Indonesia are DANA, GO-PAY, SHOOPEPAY. LINK-AJA. E-wallet applications in Indonesia have their respective advantages and disadvantages and experience ups and downs for their users (https://divedigital.id)

The most widely used digital wallet users, namely the top 3 were followed by GOPAY with a percentage of $83.3 \%$, OVO was in second place with a percentage of $81.4 \%$ and the third place was followed by the DANA application of $68.2 \%$.

The reason the majority of respondents chose this digital wallet was that respondents believed in their products, they need to buy and the e-wallet application provided useful features, made transactions easier, and could save time because consumers did not have to come to a place for payment transactions (https: //databooks.katadata.co.id). The increase in users of non-cash payments has increased every year. This can be underlined that there is a change in the mindset of the people that dominate the use of facilities that can make it easier for users to make transactions. People's lifestyle changes are influenced by several factors. These changes can be positive and negative depending on the perceptions of each individual. The use of e-commerce in Indonesia is currently the highest followed by the Shopee application. This is in line with the e-wallet owned by Shopee, known as ShopeePay, which can grab the attention of many people to enjoy the facilities that are served.Research based on Snapcart data has resulted in data that fintech or a merger between technology and financial systems in ShopeePay's fintech payments in the June-August 2020 period with 1000 respondents succeeded in dominating and seizing the positions of OVO and GoPay. Market share noted that ShopeePay obtained the largest market share of total transaction value at $34 \%$ of the total e-wallet transactions in Indonesia while OVO was 25\%, GoPay was 16\%, DANA was $17 \%$ and LinkAja was $9 \%$. The largest number of payment fintech users was obtained by ShopeePay at $68 \%$ and followed by Ovo and GoPay applications. (https://databoks.katadata.co.id).During the corona pandemic in Indonesia, the PSBB was enforced. Bank Indonesia recorded an increase in payment transactions using the non-cash system reaching a percentage of $64.48 \%$ and the growth in digital transaction volume grew $37.35 \%$ annually. This is due to the ease with which consumers receive transactions and is supported by changes in the new normal era. The convenience in this application provides features that can be accessed by users to continue the method of purchasing an item or service. (https://money.kompas.com)

According to Abrilia (2020), Ease will be one of the factors in using e-wallet applications so that it can make it easier for users to carry out transaction activities effectively and efficiently. The ShopeePay application provides many features that make it easy for users to make transactions and top up balances easily. The features that support this application are online shopping payments at the Shopee marketplace, Pay Bills, Pay Credit, getting lots of top-up vouchers, and shop. Supporting data informs that the highest ewallet transactions in Indonesia are obtained by shopee pay by $97 \%$ of users taking advantage of the convenience of the ShopeePay feature to shop online, the second-order is obtained to pay for motorbikes/transportation by $68 \%$, while the last order is obtained by OVO by $59 \%$ for topping up online pulses. The linkage of these data can be concluded that the ease with which consumers can shop online is accompanied by changes in people's lifestyles. This happened because in 2020 Indonesia held the PSBB during the Covid-19 pandemic which encouraged people to live in a new normal by minimizing outdoor activities and limiting socializing by maintaining distance. These changes will form a new lifestyle and mindset for people in Indonesia which is supported by the ShopeePay feature which makes it easier for people to adopt a new lifestyle by reducing physical activity with other people, without having to come to the store to buy necessities and enjoy promos and vouchers when shopping. online at ShoppePay. The decline in e-wallets during the pandemic consumers took more advantage of online shopping rather than using GoPay to transact transportation for travel. (https://katadata.co.id) In 2019 Gojek achieved a doubling of revenue growth in the last 12 months, the number of GoFood service users also doubled 2019. During the Covid-19 pandemic, Gojek partner income decreased by $62 \%-85 \%$, GoFood experienced a comparable drop. GoCar 
and GoRide transportation experienced a decrease in service requests by $49 \%-69 \%$ compared to before the Covid pandemic. (https://katadata.co.id). Based on this information, it can be concluded that there are changes in people's mindsets and lifestyles that are influenced by several factors. Changes in mindset during the pandemic, the increasing number of people using convenience facilities for non-cash transactions, while changes in lifestyle during this pandemic many people have changed the way they meet their needs by transacting to shop online.

Previous research conducted by (Made et al., 2016) found that the perception of ease of use had a positive effect on the intention to use Mobile Commerce in Denpasar City. This happens because the higher the user-perceived convenience, the higher the user's intention to use non-cash payments. The difference in the results of research conducted by (Kanchanatanee, 2014) concluded that perceived ease of use had a direct negative effect on the intention to use e-marketing, but had an indirect effect through attitudes towards the use of e-marketing. The negative result is because other factors can make consumers have a negative perception of the ease of intentions. The existence of individual attitudes in making use of it can affect individual attitudes. Attitude research was conducted by (Wibowo, 2008) with the result that it did not affect the perceived ease of user attitudes. The reason for this result is that the use of technology which is carried out regularly and in a prolonged manner will cause the user to ignore the attitude towards the use of technology. Research by Umaningsih \& Wardani (2020) shows a positive influence between security and the intention to use e-money. Security will protect personal data that not just anyone can access the data of other users. Users will find it easy to transact if it is coupled with the confidence in the security provided to minimize the risks posed by transactions. Research (Syarifuddin, 2018) using intervening variables shows that the perception of security directly affects attitudes and indirectly affects perceptions of security on intentions and behavior through attitudes. The role of consumer attitudes can influence the intention to use. It can be concluded that the more guaranteed and fulfilled security in using e-wallets can increase the use of ewallets. Supported by research (Arpaci et al., 2015) concluded that when the perceived ease of use is low, the user's attitude will be low which can result in a positive attitude in the use of technology.Previous research regarding attitudes and intentions to use was carried out by (Larasati \& Anik, 2019) concluded that attitude has a positive effect on the intention to use.

This is because when the user's attitude is high, it can increase the user's intention to use non-cash payments. Supporting research related to attitudes influencing intention was carried out by (Hussein, 2017) The existence of unexpected factors as a determining factor to influence intention which can result in a decrease in user attitudes. Attitudes can have a strong, direct impact and influence factors with positive or negative results on the user's intention to use technology (Jahangir \& Begum, 2008). The contradictory results made by (Rochmawati \& Bambang, 2012) show that the results of attitudes do not affect intention. This is due to the lack of understanding of respondents in using credit cards and using them only as needed without any prolonged use. In this study, other factors can influence intention, namely subjective norms, perceived risk, and perceived benefits.Researchers chose a location in Madiun, Due to changes in the use of e-money payments, this will increase the number of e-wallet users to get the features that are obtained. Information directly related to e-wallet users in the Madiun area comes from the surrounding environment who has used a lot of e-wallet shopeepay for transactions. Based on data related to internet development, the city of Madiun is designated as a city with a modern broadband city. This program is a collaboration program with Telkom with 1,500 wifi points in Madiun. It can be concluded that the people of the Madiun area can easily reach and access the internet network easily and accessed for free. The existence of this ewallet requires a stable internet connection with this, the public can easily access e-wallets with internet support. (https://madiuntoday.id) The increase in the use of non-cash payments using digital wallets is one of the factors for the problems described above. In addition, choosing in Madiun because this phenomenon is the latest and the lack of e-wallet researchers, especially ShopeePay in the region. Based on this, the researcher conducted a study entitled "The Effect of Perceived Ease and Perception of Security on Intention to Use ShopeePay through Attitude as an Intervening Variable in Madiun". 


\section{THEORETICAL REVIEW \\ Perception of Ease}

Perceived ease of use is a level of condition where someone believes that using a technology system does not require excessive effort or that the technology system can be used easily. Davis (1989) (in Rani, 2020) In line with the definition presented by (Made et al., 2016) The perception of convenience is a technology that is trusted by someone to use technology that is free of effort. Users will find it easier to apply technology without causing burdensome use efforts.

\section{Perceptions of Security}

Security is protected from threats that can create conditions, circumstances, or events that lead to data misuse, fraud, data modification (Bojang, 2017). Security in technology with guaranteed information privacy and an understanding of technology for users will make users believe in using technology in transactions. Information security can be identified as information protection that can minimize the risk of various threats. Security can be realized by understanding users related to technology, implementing procedures by policies, and functioning to provide security for users (Irawan, 2020). Each individual's perception of safety is different from the evaluation that the user generates.

\section{Intention to Use}

Intention to use can be identified as the will of an individual desire to perform certain behaviors (Made et al., 2016). The individual intention is based on the behavior of each individual which can be influenced by several factors to be able to evaluate negatively or positively in deciding the intention to use. Intention to use according to (Anggraeni, 2015) behavior that tends to continue and keep using technology.

\section{Attitude}

Attitudes can be formed, studied and attitudes can change according to the situation faced by consumers (Ari Kadi, 2016). Feelings can be in the form of partial or supportive reactions or feelings of impartiality and unsupporting in these conditions (Sidanti \& Hatmawan, 2017) So it can be said that the attitude of an individual with other individual attitudes varies to evaluate or conclude the behavior caused after being influenced by several factors -factor. The indicators in this study are belief, perception, emotion, motivation (Dwi Prasetyo, 2019).

\section{Conceptual framework}

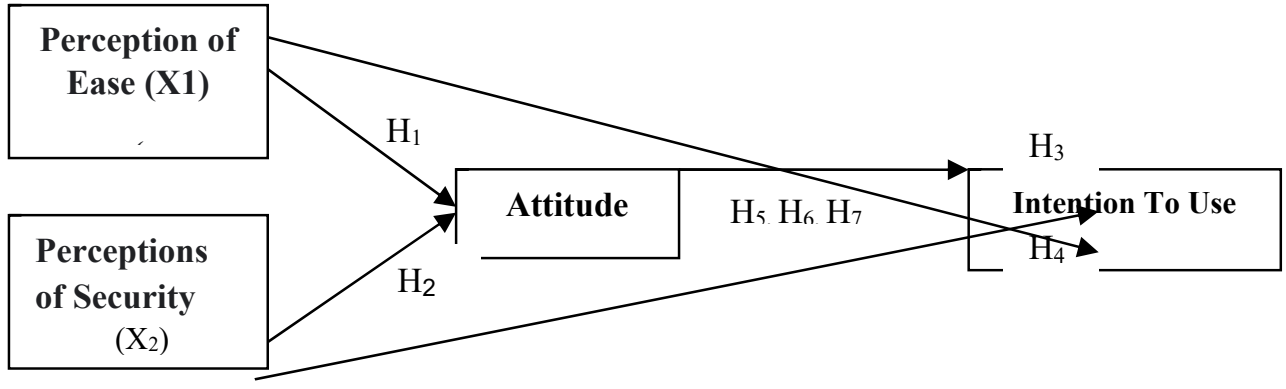

Sources : Modification (Syarifuddin, 2018), (Larasati \& Anik, 2019), (Novita \& Giantari, 2016)

\section{Research Hypothesis}

$\mathrm{H} 1=\mathrm{it}$ is suspected that there is a significant influence on perceived convenience on the attitudes of ShopeePay users in Madiun

$\mathrm{H} 2=$ it is suspected that there is a significant effect of perceived security on the attitudes of ShopeePay users in Madiun

$\mathrm{H} 3=$ it is suspected that there is a significant influence between perceived ease of use and intention to use ShopeePay in Madiun

$\mathrm{H} 4=$ it is suspected that there is an influence between the perception of security on the intention to use ShopeePay in Madiun

$\mathrm{H} 5=\mathrm{it}$ is suspected that there is a significant influence on user attitudes towards the intention to use ShopeePay in Madiun

H6 = it is suspected that there is a significant influence on perceived ease of use through the attitude of ShopeePay users in Madiun 
$\mathrm{H} 7=\mathrm{it}$ is suspected that there is a significant influence on perceived ease of use through the attitude of ShopeePay users in Madiun

\section{RESEARCH METHODS}

\section{Place and time of research}

The research was carried out in the Madiun City and Regency areas. The increase in e-wallet users has made e-wallets in great demand for payment transactions. When the research was carried out in November 2020 - March 2021

\section{Research design}

Quantitative descriptive research is used in this research. Quantitative descriptive research is the existence of one or more variables that are interrelated with the population or sample and data analysis is used to test provisional hypotheses or temporary answers (Sugiyono, 2013). The survey method used in this study can provide questions to respondents then be analyzed and processed to determine research conclusions. Data collection was carried out through a questionnaire. The analysis tool uses the IBM SPSS Statistics 20 application

\section{Population, Sample, and Sampling Technique}

The population in this study is the Madiun community. The sample in this study were respondents who had never used ShopeePay in Madiun. There is an unlimited number of studies in research due to a large number of e-wallet users. The sample in this study used a nonprobability sampling technique by limiting respondents by not allowing them to return to be part of the sample and collecting data using purposive sampling, namely the sampling technique using certain considerations (Sugiyono, 2013).

The criteria for the sample of respondents are as follows:

a. Respondents are at least 17 years old

b. Never used ShopeePay e-wallet

c. Domiciled in the City and District of Madiun

This study uses an infinite population formula or an unknown population because the population of ShopeePay respondents in Madiun cannot be known with certainty the number of users. Roscoe 1975 (In Ferdinand, 2014) reveals some guidelines in sample size, namely that the sample size can be said to be feasible if there are 30-500 samples in the study. So, in this study, 150 samples were taken. This research data collection is through questionnaires. This method is useful for obtaining primary data directly by making questions related to the questionnaire systematically and distributed to the public who are respondents to fill out the questionnaire (Kurniawan \& Puspitaningtyas, 2016). This study uses a google form questionnaire due to restrictions on direct social interaction during the Covid-19 pandemic.

\section{ANALYSIS RESULTS \\ Classic assumption tests \\ a. Normality test}

This test is used to determine whether the data is normally distributed or not (Ghozali Imam, 2018). Normality testing can be seen by using SPSS and the test results are determined in the Kolmogorov-Smirnov test section, the Asymp. Sig (2-tailed) value is as follows

Table 1. Normality Test Results

One-Sample Kolmogorov-Smirnov Test

\begin{tabular}{|ll|r|}
\hline & & Unstandardized Residual \\
\hline $\mathrm{N}$ & & 150 \\
Normal Parameters ${ }^{\mathrm{a}, \mathrm{b}}$ & Mean & $0 \mathrm{E}-7$ \\
& Std. Deviation & 3.28636135 \\
& Absolute & .067 \\
Most Extreme Differences & Positive & .062 \\
& Negative & -.067 \\
Kolmogorov-Smirnov Z & & .823 \\
Asymp. Sig. (2-tailed) & & .507 \\
\hline
\end{tabular}


a. Test distribution is Normal.

b. Calculated from data.

\section{SumberSoSource : Output SPSS}

The results of table 1 can be seen that the normality test can be seen in the Asymp.Sig (2-tailed) value section of 0.507 . This result is significant for all variables $>0.05$. Then the results of the normality test can be said that the residual data has been normally distributed.

\section{b. Multicolonierity Test}

This test is used to test the correlation between independent variables. This test can be seen from the VIF and Tolerance values with the provisions of the tolerance value and variance inflation factor (VIF) so that there is no multicollinearity (Ghozali Imam, 2018).

Table 2. Multicolonierity Test Results

\section{Coefficients $^{\mathrm{a}}$}

\begin{tabular}{|c|c|c|}
\hline \multirow[t]{2}{*}{ Model } & \multicolumn{2}{|c|}{ Collinearity Statistics } \\
\hline & Tolerance & VIF \\
\hline (Constant) & & \\
\hline Perception of Use & .604 & 1.656 \\
\hline Perception of Security & .668 & 1.496 \\
\hline Attitude & .603 & 1.659 \\
\hline
\end{tabular}

a. Dependent Variable: Intention To Use

\section{Source : Output SPSS}

Test results From table 2, the variables of perceived convenience, security perceptions, and attitudes indicate different results for each. The results of all tolerance and VIF of all variables show that the value exceeds 0.1 or $10 \%$ and the VIF value of all variables obtains a value less than 10 . Based on these results it can be concluded that the tolerance and variance inflation factor (VIF) values obtained results that did not occur. the strong correlation between independent variables.

\section{Heteroscedasticity Test}

This test is used to test the regression model regarding the inequality of vatiance from the residuals of the first observation with other observations (Ghozali Imam, 2018). The heteroscedasticity test can be seen from the pattern of the scatterplot chart results between ZPRED and SRESID. The results of the heteroscedasticity test are as follows:

Fig 1.Heteroscedasticity Test Results

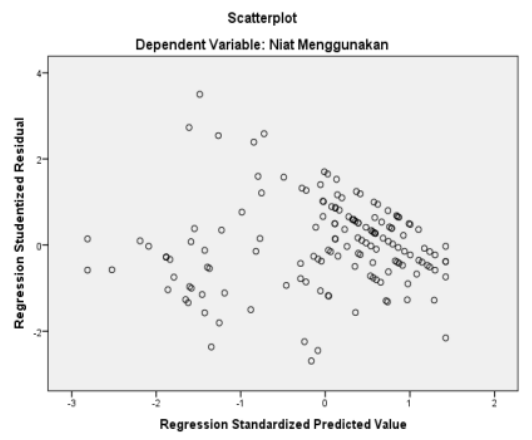

\section{Source : Output SPSS}

The results of Figure 1 can be concluded that the points in the scatterplot do not form a clear pattern and the points spread above and below the number 0 on the $\mathrm{Y}$ axis. Then the results of the test do not occur heteroscedasticity.

\section{Hypothesis testing}

Research using intervening variables was analyzed with multiple linear regression analysis expanded using path analysis processed with the SPSS version 20 application program.

The path analysis stages are as follows:

1. Formulate structural equations 
2. Sub-structural 1: $Z=P X 1 Z+P X 2 Z+e 1$

3. Substructural 2: $\mathrm{Y}=\mathrm{PX} 1 \mathrm{Y}+\mathrm{PX} 2 \mathrm{Y}+\mathrm{PZY}+\mathrm{e} 2$

4. Calculating the path coefficient based on the regression coefficient and regression coefficient for each sub-structural that has been formulated. Partially compute path coefficients.

Fig 2. Path Analysis Model

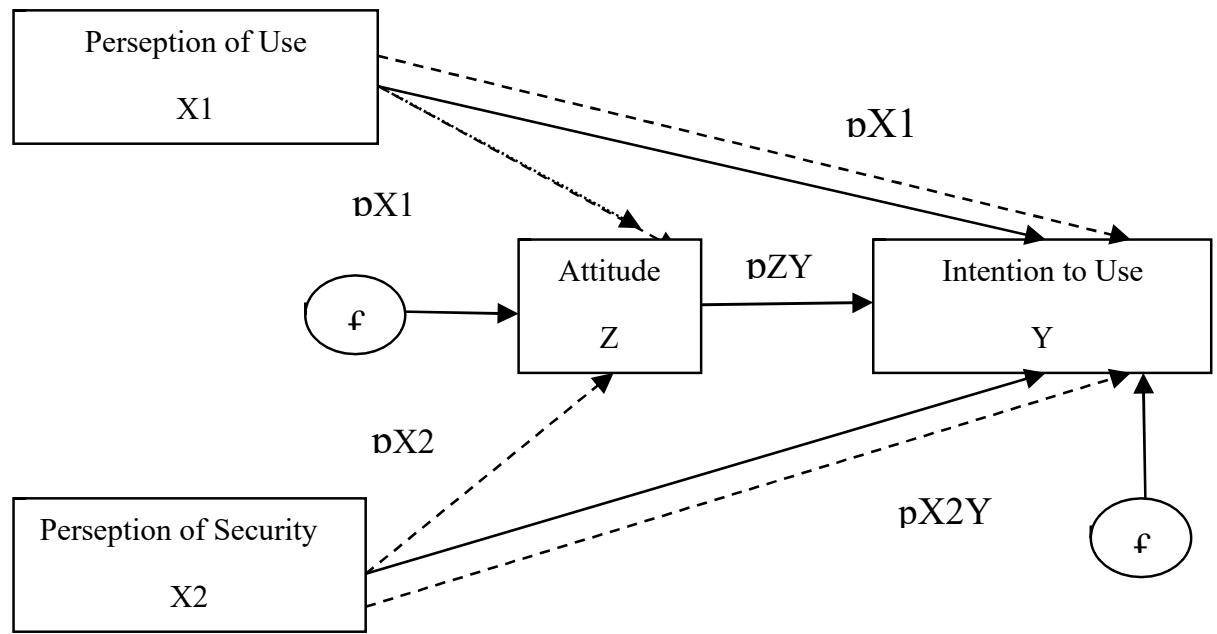

\section{Sub-structural direct effect test 1}

Sub-structural regression analysis 1 was used to examine the relationship between the independent variables and the intervening variables.

\section{1) Test of Significance of Individual Parameters (t-test)}

The t-test is a partial test used to determine the effect of perceived ease (X1), perceived security (X2) on attitudes (Z). A partial test of this research was conducted to test the effect individually or individually between perceived ease of use, perception of security on attitudes partially. The results of the t-test in this study are as follows

Table 3. Results of Sub-structural T-Test I

\section{Coefficients $^{\mathbf{a}}$}

\begin{tabular}{|c|c|c|c|c|c|}
\hline \multirow[t]{2}{*}{ Model } & \multicolumn{2}{|c|}{$\begin{array}{c}\text { Unstandardized } \\
\text { Coefficients }\end{array}$} & $\begin{array}{l}\text { Standardized } \\
\text { Coefficients }\end{array}$ & \multirow[t]{2}{*}{$\mathrm{t}$} & \multirow[t]{2}{*}{ Sig. } \\
\hline & B & $\begin{array}{l}\text { Std. } \\
\text { Error }\end{array}$ & Beta & & \\
\hline (Constant) & 4.500 & 1.114 & & 4.040 & .000 \\
\hline${ }^{1}$ Persepsi of Use & .459 & .080 & .427 & 5.736 & .000 \\
\hline Persepsi of Security & .281 & .071 & .294 & 3.945 & .000 \\
\hline
\end{tabular}

a. Dependent Variable: Attitude

\section{Source : Output SPSS}

The results from the table above can be processed into a regression equation for these variables as follows:

$\mathrm{Z}=\mathrm{PX} 1 \mathrm{Z}+\mathrm{PX} 2 \mathrm{Z}+\mathrm{e} 1$

$=0.427 . \mathrm{X} 1+0.294 . \mathrm{X} 2+0.776$

a) The perceived convenience variable (X1) shows the sig value. $0.000<0.05$ and the value of tcount (5.736) $>\mathrm{t}$ table (1.976) means that $\mathrm{H} 0$ is rejected and $\mathrm{Ha}$ is accepted. So it can be concluded that perceived ease has an effect on attitudes

b) The security perception variable (X2) shows the sig value. $0.000<0.05$ and the value of tcount (3.945) $>$ t table (1.976) means that $\mathrm{H} 0$ is rejected and $\mathrm{Ha}$ is accepted. So it can be concluded that the perception of security affects attitudes 


\section{Coefficient of Determination (R2)}

The coefficient of determination (R2) is to test how big the perceived convenience variable is, the overall perception of security can explain the attitude variable. The results of the analysis of the coefficient of determination are as follows:

Table 4. Coefficient of Determination

Model Summary ${ }^{b}$

\begin{tabular}{|c|c|c|c|c|}
\hline Model & $\mathrm{R}$ & $\begin{array}{c}\mathrm{R} \\
\text { Square }\end{array}$ & $\begin{array}{l}\text { Adjusted } \\
\text { R Square }\end{array}$ & $\begin{array}{l}\text { Std. Error of } \\
\text { the Estimate }\end{array}$ \\
\hline 1 & $.630^{\mathrm{a}}$ & .397 & .389 & 3.30864 \\
\hline
\end{tabular}

a. Predictors: (Constant), Perception of Security

Perception of Use

b. Dependent Variable: Attitude

\section{Source : Output SPSS}

The results of the table analysis above can be informed that the value of the R-square (R2) is 0.397 or $39.7 \%$. So the variable perception of ease, perception of security can be explained by $39.7 \%$ of attitudes and the remaining 0.603 or $59.7 \%$ is explained by other variables outside of this study. Value $€ 1=\sqrt{ }(1-0.397=$ 0.776).

\section{Sub-structural direct effect test II}

1) Test of Significance of Individual Parameters ( $t$ test)

The partial test was used to determine the effect of perceived convenience (X1), perceived security (X2) and attitude $(\mathrm{Z})$ on intention to use $(\mathrm{Y})$. This research $\mathrm{t}$ test was conducted to test the effect of individually or of each variable partially.

Table 5. Results of Sub-structural T-Test II

Coefficients $^{\mathrm{a}}$

\begin{tabular}{|c|c|c|c|c|c|}
\hline \multirow[t]{2}{*}{ Model } & \multicolumn{2}{|c|}{$\begin{array}{c}\text { Unstandardized } \\
\text { Coefficients }\end{array}$} & \multirow{2}{*}{$\begin{array}{c}\begin{array}{r}\text { Standardized } \\
\text { Coefficients }\end{array} \\
\text { Beta }\end{array}$} & \multirow[t]{2}{*}{$\mathrm{t}$} & \multirow[t]{2}{*}{ Sig. } \\
\hline & B & $\begin{array}{l}\text { Std. } \\
\text { Error }\end{array}$ & & & \\
\hline (Constant) & 1.254 & 1.012 & & 1.239 & .217 \\
\hline $\begin{array}{l}\text { Perception of } \\
1 \text { Use }\end{array}$ & .216 & .076 & 192 & 2.830 & .005 \\
\hline $\begin{array}{l}\text { Perception of } \\
\text { Security }\end{array}$ & .155 & .065 & .155 & 2.404 & .017 \\
\hline Attitude & .570 & .071 & .544 & 8.016 & .000 \\
\hline
\end{tabular}

\section{Sumber : Output SPSS}

The results from the table above can be processed into a regression equation for these variables as follows:

$\mathrm{Y}=\mathrm{PX} 1 \mathrm{Y}+\mathrm{PX} 2 \mathrm{Y}+\mathrm{PZY}+\mathrm{e} 2$

$=0.192 . \mathrm{X} 1+0.155 . \mathrm{X} 2+0.544 . \mathrm{Z}+0.637$

a) The perceived convenience variable (X1) shows the sig value. $0.005<0.05$ and the value of tcount (2.830)> $\mathrm{t}$ table (1.976) means that $\mathrm{H} 0$ is rejected and $\mathrm{Ha}$ is accepted. So it can be concluded that the perceived ease of use affects the intention to use.

b) The security perception variable (X2) shows the sig value. $0.007<0.05$ and the value of tcount (2.404) $>t$ table (1.976) means that $\mathrm{HO}$ is rejected and $\mathrm{Ha}$ is accepted. So it can be concluded that the perception of security affects the intention to use. 
c) The attitude variable $(Z)$ shows the sig value. $0.000<0.05$ and the value of tcount $(8,016)>t$ table $(1.976)$ means that $\mathrm{H} 0$ is rejected and $\mathrm{Ha}$ is accepted. So it can be concluded that attitude affects the intention to use

\section{1) Coefficient of Determination (R2)}

The coefficient of determination (R2) is to test how big the variables of perceived convenience, security perceptions, and overall attitudes can explain the variable intention to use. The results of the analysis of the coefficient of determination are as follows:

Table 6. Results of the Coefficient of Determination

Model Summary ${ }^{b}$

\begin{tabular}{|l|r|r|r|r|}
\hline Model & R & R Square & $\begin{array}{c}\text { Adjusted R } \\
\text { Square }\end{array}$ & $\begin{array}{l}\text { Std. Error of } \\
\text { the Estimate }\end{array}$ \\
\hline 1 & $.771^{\mathrm{a}}$ & .594 & .586 & 2.85180 \\
\hline
\end{tabular}

a. Predictors: (Constant), Attitude, Perception of Security, Perception Of Use

b. Dependent Variable: Intention to Use

\section{Sumber : Output SPSS}

The results of the table analysis above can be informed that the value of the R-square (R2) is 0.594 or $59.4 \%$. So the variables of perceived convenience, perceptions of security, attitudes can be explained by $59.4 \%$ of the intention to use and the remaining 0.406 or $40.6 \%$ can be explained by other variables outside of this study. Value $€ 1=\sqrt{ }(1-0.511=0.637)$

\section{Path Analysis}

Path analysis is an expansion analysis method of multiple linear regression analysis used to test intervening variables related to the strength of the relationship between the dependent variable, the independent variable, and the mediating variable (Ghozali Imam, 2018).

a. Path Analysis Interpretation

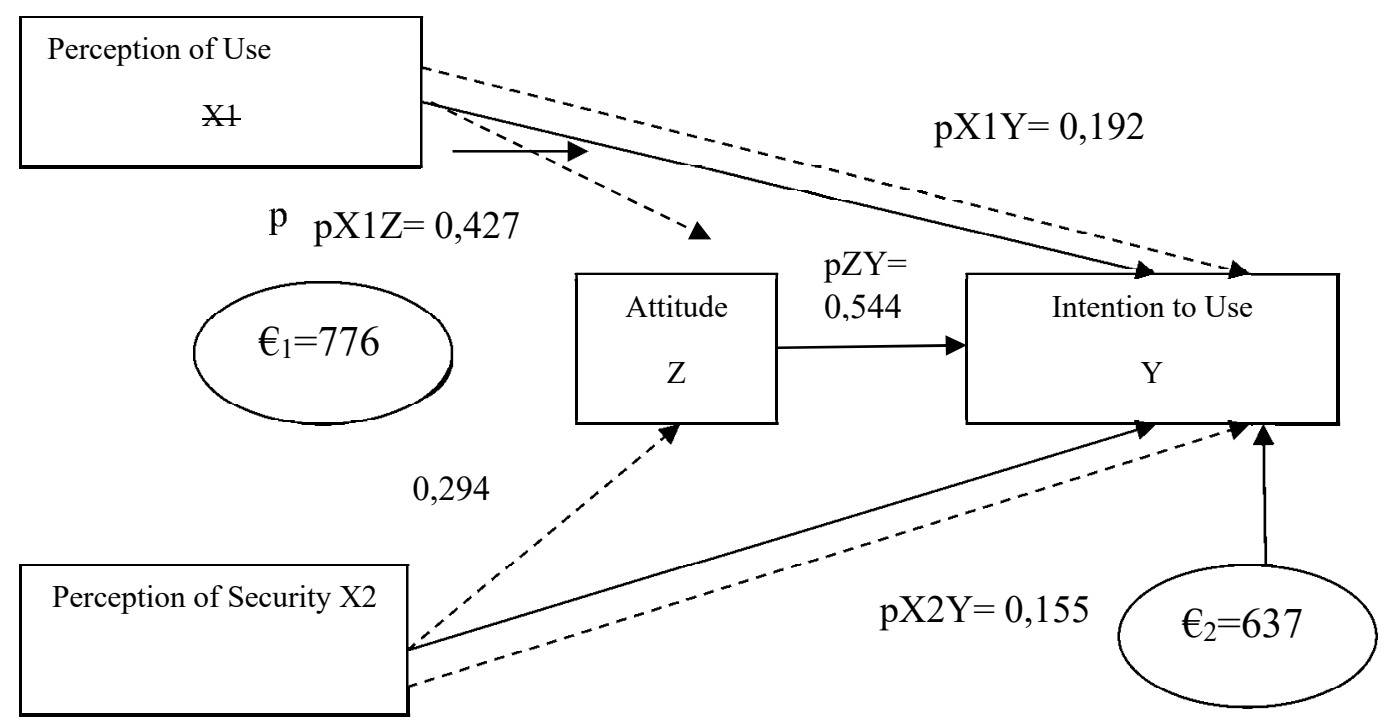

Fig 3. An empirical causal relationship analysis path framework Direct and Indirect Influence

The effect of perceived ease of use on intention to use through user attitude in Madiun

In the sub-structural path analysis 1 , it explains the direct and indirect effects with the calculation results obtained based on the analysis path as follows:

Direct Effect $(\mathrm{pYX} 1)=0.192$

Indirect Effect $(\mathrm{pZX} 1 * \mathrm{XYZ})=0.427 \times 0.544$

$$
=0.23228
$$


Total Effect $0.192+0.23228=0.424288$

From the calculation of the path analysis equation, it can be seen that the result of the indirect effect is 0.23228 with a total direct and indirect effect of 0.424288 .

The mediation test uses the online sobel test via https://www.danielsoper.com/. The following is the calculation result from the online sobel test:

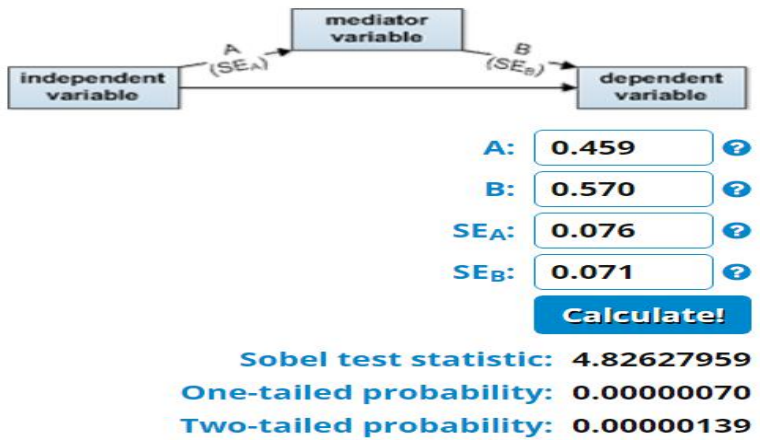

Fig 4. Sobel structural results 1

The results of the structural online sobel test 1 obtained a statistical sobel test value of $4,826>t$ table of 1.96 with a significance level of $5 \%$ with a two-tailed value of $0.000<0.05$, it can be concluded that attitude variables can mediate the perceived ease of use towards the intention to use accordingly. with the sobel test requirements.

2. he results of the structural online Sobel test 1 obtained a statistical Sobel test value of $4,826>t$ table of 1.96 with a significance level of $5 \%$ with a two-tailed value of $0.000<0.05$, it can be concluded that attitude variables can mediate the perceived ease of use towards the intention to use accordingly. with the with the Sobel test requirements.

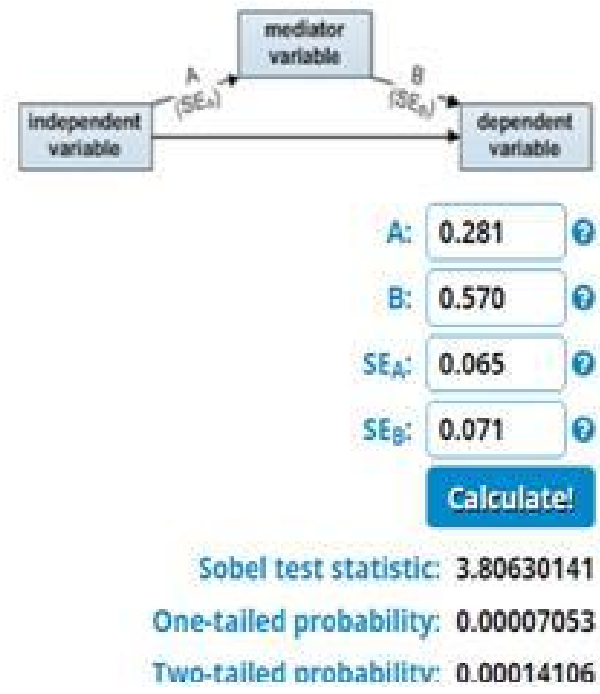

Fig 5. Structural sobel results II

The results of the structural online sobel test II obtained that the sobel test statistic is tcount of 3.806 $>t$ table of 1.96 with a significance level of $5 \%$ with a two-tailed value of $0.000<0.05$. with the sobel test requirements.

\section{Discussion}

\section{The influence of perceived ease of use on user attitudes}

Esting the first hypothesis of this study states that perceived convenience partially affects the attitudes of ShopeePay users in Madiun. This study obtained the results of the t-test with a t-count value of 5.736 greater than the t-table value of 0.1976 with a sig value. $0.000<0.05$. This is due to the convenience provided by Shopee to users in using payment transactions. The results of this study are comparable to research conducted by (Widodo \& Putri, 2017), the study found that perceived ease has an effect on attitudes because the higher the level of convenience provided, the higher the user's attitude in using these facilities. 


\section{The effect of security perceptions on user attitudes}

Testing the second hypothesis of this study informs that security perceptions partially influence the attitudes of ShopeePay users in Madiun. The results of this study obtained the results of the t-test with a tcount value of 3.945 greater than the $t$-table value of 0.1976 with a sig value of $0.000<0.05$. This is due to the level of security provided by ShopeePay. For users, security is important to ensure data security in making transactions. The results of research conducted by (Alraja et al., 2021) show the same results, namely the perception of security affects attitudes because security can minimize interference or abuse of unauthorized and suspicious access rights by irresponsible parties.

\section{The effect of perceived ease of use on intention to use}

The testing of the third hypothesis of this study explains that perceived convenience partially affects the intention to use ShopeePay in Madiun. The results of this study obtained t-test results with an at-count value of 2.830 greater than the t-table value of 0.1976 with a sig value of $0.005<0.05$. The results are influential because potential users can enjoy easy facilities with access to payment transactions that do not require a lot of time and effort and increase the response to use for intending to use. The results of influential research conducted by (Anggraeni, 2015) explained that the perception of convenience is the main aspect for users in making transactions and can increase the intention to buy. However, the difference in research conducted by (Kanchanatanee, 2014) obtained results had no effect because other factors could significantly increase the intention to use.

\section{The effect of perceived security on intention to use}

The fourth hypothesis testing of this study shows that the perception of security has a partial effect on the intention to use ShopeePay in Madiun. The results of this study obtained t-test results with an at-count value of 2.404 greater than the t-table value of 0.1976 with a sig value of $0.017<0.05$. These results are based on the majority of potential users making security an important factor in the payment process for transactions, especially at ShopeePay.Similar research with influential results was carried out by (Umaningsih \& Wardani, 2020) explaining that with security, users will trust in the assurance of security and continue to intend to use payment transactions.

\section{The Effect of User Attitudes on Intention to Use}

Testing the fifth hypothesis of this study explains that attitude partially influences the intention to use ShopeePay in Madiun. The results of this study obtained t-test results with an at-count value of 8.016 greater than the t-table value of 0.1976 with a sig value of $0.000<0.05$. This is because there are factors related to attitude and intention to use. Users will be sure to make purchase intentions if the previous factors influence the intention to use. Research conducted by (Larasati \& Anik, 2019) obtained positive results because of the high attitude toward using transactions

\section{The effect of perceived ease of use on intention to use is through user attitudes}

The sixth hypothesis testing of this study explains that the perceived ease of use intention is through the attitude of ShopeePay users in Madiun. This research has direct and indirect effects which are carried out using path analysis with the Sobel test with an online counting application.Researching with the results of the structural mediation test I obtained the value of tcount $>$ table $=4.826>1.96$. So it can be concluded that the Sobel test results meet the requirements that the variable perceived ease of use is mediated by an accepted attitude and there is a mediating effect. This is proportional to the results of the indirect effect.

The result of the direct effect is 0.192 and the indirect effect is 0.23228 with a total direct and indirect effect of 0.424288 . The results of the direct and indirect effect can be concluded that the direct effect between perceived ease of use and intention to use is smaller than the indirect effect between perceived ease of use on intention to use through attitude. So it can be concluded that prospective users will respond positively if the facilities enjoyed can make it easier to use payment transactions and vice versa if users feel that their attitude is not fasting towards convenience, it will affect their intention to use them.Differences in the results of research by (Rochmawati \& Bambang, 2012) have no effect because high or low user attitudes do not have an impact on intention to use which is based on a lack of understanding regarding prolonged use, use is only done as necessary. 


\section{The effect of security perceptions on intention to use through user attitudes}

The seventh hypothesis testing of this study shows that the perception of security on intention to use is through the attitudes of ShopeePay users in Madiun. This research has direct and indirect effects which are carried out using the online Sobel test path analysis. The research results of the structural mediation test II obtained the value of tcount $>$ table $=3.806>1.96$. So it can be concluded that the research hypothesis on security perceptions of intention to use is mediated by acceptance and there is a mediating effect. These results are comparable to the results of the indirect effect test.This study obtained a direct effect of 0.155 and an indirect effect of 0.159936 with a total direct and indirect effect of 0.314936 .

Judging from the results of the direct and indirect effect, it can be concluded that the direct influence between perceptions of security on intention to use is smaller than the indirect effect between perceived ease of use on intention to use through attitude. So it can be concluded that the intervening variable has a high influence in influencing the intention to use. This can be concluded. as evidenced by the answer of the respondent who dominates the selection of statements related to "I believe payment using Shopeepay is safe".This will increase the respondent's attitude and intention to use if the security obtained can guarantee user privacy. So, the attitude of potential users in using shopeepay transactions can increase users' intention to use it will also increase. The results of this study are supported by (Syarifuddin, 2018) obtaining the results of the intervening variable, which shows that security perceptions directly affect attitudes and indirectly affect attitudes towards intentions. This is because the higher the user's security level when making ShopeePay transactions, the higher the attitude and intention to use.

\section{CONCLUSION}

Based on the results of the explanation and discussion of the research above, the conclusions from the results of this study are as follows:

1. Perceived convenience has a significant effect on the attitude of using Shopeepay in Madiun, meaning that if prospective shopeepay users enjoy the convenience of Shopeepay when making transactions, the user will show a positive attitude towards payment transactions, and the higher the convenience provided by Shopee, the higher the user's positive perception when doing transaction.

2. Perceptions of security have a significant effect on the attitude of using Shopeepay in Madiun. This means that the level of security facilitated by Shopee for shopee users will show a positive user attitude if the confidentiality of privacy data from the user is guaranteed when making transactions and the higher the level of security, the higher the user's attitude in using it.

3. Perceived convenience has a significant effect on the intention to use Shopeepay in Madiun. That is, prospective users will continue their intention to use Shopeepay when making transactions, they get convenience facilities such as not requiring a lot of time, effort, making transactions easy, and the higher the perceived ease of use by the user, the higher the user's intention to immediately try and continue the transaction in a prolonged manner.

4. Perception of security has a significant effect on the intention to use Shopeepay in Madiun. This means that perceived user security perceptions can increase usage intentions in conducting transactions and guarantee confidentiality and potential users will conduct trials to find out the security that is generated if the use produces positive and safe results, which will make users intend to use shopeepay continuously.

5. Attitude has a significant effect on the intention to use Shopeepay in Madiun. This means that attitudes and intentions to use are interrelated. This is because the user's attitude can be an intermediary factor between the intention and the independent variable. The results show that attitude is an important intervening variable in influencing the intention to use a variable. If the attitudes of potential users are high towards technology, it will be able to increase the intention to use technology sustainably.

6. Perceived ease has an indirect and mediating effect on the intention to use through the attitude of Shopeepay users in Madiun. This means that attitude as an intermediary variable between perceived ease of use and intention to use can be a determining factor for continuing the intention to use. So, 
when the perception of convenience is high, it will be able to increase the user's continuous intention and a high-use attitude can influence users to intend to useShopeepay. Conversely, if the attitude of use is low, it can reduce the attitude of using it to intend to use the ShopeePay E-wallet.

7. Perceived ease has an indirect and mediating effect on the intention to use through the attitude of Shopeepay users in Madiun. This means that security in technology is the most important thing to support users in transactions and the higher the user's attitude in security perceptions will increase the intention to continue using transactions.

\section{REFERENCES}

[1] Abrilia, N. (2020). Pengaruh Persepsi Kemudahan dan Fitur Layanan Terhadap Minat Menggunakan E-Wllet Pada Aplikasi Dana Surabaya. 8(3), 1006-1012.

[2] Alwafi, F., \& Magnadi, R. (2016). Pengaruh persepsi keamanan, kemudahan bertransaksi, kepercayaan terhadap roko dan pengalaman berbelanja terhadap minat beli secara online pada situs jual beli tokopedia.com. Diponegoro Journal Og Management, 5, 1-15.

[3] Anggraeni, R. (2015). Pengaruh Persepsi Kemudahan Penggunaan dan Persepsi Kegunaan Terhadap Niat Untuk Menggunakan dan Penggunaan Aktual Layanan Jejaring Sosial Berbasis Lokasi (Studi pada Mahasiswa Fakultas Ekonomi dan Bisnis Universitas Brawijaya Malang). 44-52.

[4] Ari Kadi, D. C. (2016). Peran Sikap sebagai Pemediasi terhadap Pengaruh Persepsi Harga dan Persepsi Kualitas pada Niat Beli (Survei Niat Beli Konsumen pada Kerajinan Kulit di Kabupaten Magetan). Al Tijarah, 2(2), 211. https://doi.org/10.21111/tijarah.v2i2.743

[5] Arpaci, I., Kilicer, K., \& Bardakci, S. (2015). Effects of security and privacy concerns on the educational use of cloud services. computers in human behavior, 45, 93-98. https://doi.org/10.1016/j.chb.2014.11.075

[6] Bojang, I. (2017). Determinants of trust in b2c e-commerce and their relationship with consumer online trust: a case of Ekaterinburg, Russian federationadanya. 22. https://doi.org/https://doi.org/10.1063/1.5013938

[7] Cetin, Y. Y., \& Turetken, O. (2015). Impact of Perceived Security on Organizational Adoption of Smartphones. 18(10), 1-7. https://doi.org/10.1089/cyber.2015.0243

[8] Ferdinand, A. (2014). Metode penelitian manajemen. Badan Penerbit Universitas Diponegoro.

[9] Ghozali imam. (2018). Aplikasi analisis multivariate dengan program IBM 25. Badan Penerbit Universitas Diponegoro.

[10] Hussein, Z. (2017). Leading to Intention: The Role of Attitude with Technology Acceptance Model in ELearning. Procedia - Procedia Computer Science, 105(December 2016), 159-164. https://doi.org/10.1016/j.procs.2017.01.196

[11] Iliyin, A., \& Widiartanto. (2020). Pengaruh Persepsi Kemudahan Penggunaan Dan Persepsi Keamanan Terhadap Keputusan Penggunaan Ovo PT Visionet Data Internasional (Studi Pada Pengguna Ovo Di Kota Surakarta). Journal Ilmu Administrasi Bisnis, 9(1), 85-92.

[12] Irawan, D. (2020). Pengaruh privasi dan keamanan terhadap niat menggunakan payment fintech. 4(1), 52-62.

[13] Jahangir, N., \& Begum, N. (2008). The role of perceived usefulness, perceived ease of use, security, and privacy, and customer attitude to engender customer adaptation in the context of electronic banking. 2(1), 3240.

[14] Kanchanatanee, K. (2014). Effects of Attitude toward Using, Perceived Usefulness, Perceived Ease of Use and Perceived Compatibility on Intention to Use E-Marketing. Journal of Management Research, 6(3), 1. https://doi.org/10.5296/jmr.v6i3.5573

[15] Kurniawan, A. W., \& Puspitaningtyas, Z. (2016). Metode Penelitian Kuantitatif. Pandiva buku.

[16] Larasati, I., \& Anik, A. (2019). Pengaruh perceived ease of use dan perceived usefulness terhadap niat mengguakan internet banking dengan sikap sebagai variabel intervening. 7, 143-150.

[17] Leon, S. (2018). Service mobile apps: a millennial generation perspective. Industrial Management and Data Systems, 118(9), 1837-1860. https://doi.org/10.1108/IMDS-10-2017-0479

[18] Liébana-cabanillas, F., Luna, I. R. De, \& Montoro-, F. (2017). Intention to use new mobile payment systems: a comparative analysis of SMS and NFC payments. Economic Research-Ekonomska Istraživanja, 30(01), 724742. https://doi.org/10.1080/1331677X.2017.1305784

[19] Made, N., Puspita, A., \& Warmika, I. G. K. (2016). Peran persepsi kemudahan penggunan, persepsi manfaat dan perspsi resiko terhadap niat menggunakan Mobile Commerce Di Kota Denpasar. 5(4), 2606-2636.

[20] Madhavaiah, Irfan Bashir C. (2015). Consumer attitude and behavioral intention towards Internet banking adoption in India. https://doi.org/10.1108/JIBR-02-2014-0013 
[21] Novita, N. N., \& Giantari, I. G. (2016). Peran sikap dalam memediasi pengaruh peceived usefulness terhadap niat mmenggunakan internet banking di kota denpasar. 5(3), 1513-1541.

[22] Permana, W., \& Endang Astuti. (2012). Layanan Perpustakaan via Mobile Data. Universitas Brawijaya Press (UB Press).

[23] Putro, H., \& Haryanto, B. (2015). Factors Affecting Purchase Intention of Online Shopping in Zalora Indonesia. British Journal of Economics, Management \& Trade, 9(1),

1-12. https://doi.org/10.9734/bjemt/2015/18704

[24] Rani, D. M. (2020). Analisis Technoogy Acceptance Model (TAM) pada Aplikasi Mobile JKN.

[25] Rauniar, R., Rawski, G., Yang, J., \& Johnson, B. (2014). Technology acceptance model (TAM) and social media usage: An empirical study on Facebook. Journal of Enterprise Information Management, 27(1), 6-30. https://doi.org/10.1108/JEIM-04-2012-0011

[26] Rochmawati, S., \& Bambang, P. (2012). Pengaruh Sikap, Norma Subjektif, Kontrol Perilaku Persepsian, Persepsi Risiko, Persepsi Kebermanfaatan Terhadap Niat Penggunaan Kartu Kredit. Jurnal Ilmiah Mahasiswa FEB.

[27] Setiadi, N. (2003). Perilaku Konsumen : Perspektif Kontemporer pada Motif, Tujuaan, dan Keinginan Konsumen. Kencana Prenada Media Group.

[28] Sidanti, H., \& Hatmawan, A. A. (2017). Faktor Yang Mempengaruhi Niat Ketidakpatuhan Dalam Membayar Pajak Dengan Pendekatan Theory Of Planned Behavior (TPB). Prosiding Seminar Hasil Penelitian Dan Pengabdian Kepada Masyarakat UNIPMA, 1(1), 165-176.

[29] Singh, S. (2016). Predicting the Intention to Use Mobile Banking in India Introduction. https://doi.org/org/10.1108/IJBM-12-2016-0186

[30] Sugiyono. (2013). Metode penelitian pendidikan pendekatan kuantitatif, kualitatif, dan R\&D. Alfabeta.

[31] Sujarweni, W., \& Utami, lila retnani. (2020). The master book of SPSS : pintar mengolah data statistik untuk segala keperluan secara otodidak. Anak hebat indonesia.

[32] Sunith Hebbar, G. B. . K. and V. K. (2020). Attitude towards online shopping and its influence on purchase intentions: an urban Indian perspective. 22(3), 326-341. https://doi.org/10.1504/IJBIR.2020.10030070

[33] Syarifuddin, F. (2018). Pengaruh Persepsi Keamanan dan Kepercayaan terhadap Niat Konsumen dalam Melakukan Transaksi E-Commerce, melalui Sikap sebagai Variabel Intervening. 1, 86-96.

[34] Umaningsih, W., \& Wardani, D. (2020). Pengaruh Persepsi Kemudahan, Fitur Layanan, Dan Keamanan Terhadap Niat Menggunakan E-Money. 5, 113-119. https://doi.org/10.29407/jae.v5i3.14057

[35] Wibowo, A. (2008). Kajian tentang perilaku pengguna sistem informasi dengan pendekatan technology acceptance model (TAM).

[36] Widodo, A., \& Putri, A. S. A. (2017). Pengaruh Persepsi Kegunaan Dan Persepsi Kemudahan Penggunaan Terhadap Sikap Penggunaan Teknologi Pada Pengguna Instagram Di Indonesia (Studi Pada Followers Akun Kementerian Pariwisata @Indtravel). Journal of Secretary and Business Administration,

1(1), 18. https://doi.org/10.31104/jsab.v1i1.8 